\title{
Odnawialne źródla energii w świetle globalnego kryzysu energetycznego. Wybrane problemy, red. Franciszek Krawiec, Wydawnictwo Difin S.A., Warszawa 2010, ss. 195.
}

Publikacja jest zbiorem prac naukowców, którzy kierując się potrzebą dzielenia wiedza. postanowili zaprezentować dorobek literatury na temat Odnawialnych Źródeł Energii w zbiorze opracowanym przez Franciszka Krawca. Do współpracy przy tworzeniu książki zostali zaproszeni naukowcy pracujący na Wydziale Chemii Politechniki Gdańskiej i National Renewable Energy Laboratory w Golden, Colorado oraz pracownicy i współpracownicy Wydziału Inżynierii Produkcji Szkoły Głównej Gospodarstwa Wiejskiego. Wiedza zawarta w zbiorze kierowana jest do członków zarządów przedsiębiorstw energetycznych, personelu planowania rozwoju, badania rynku, rozwoju i budowy konwencjonalnych i odnawialnych systemów energetycznych, jak również pracowników administracji samorządowej oraz wszystkich, dla których ważne jest efektywne gospodarowanie zasobami energetycznymi. W wyniku pracy autorów, powstała publikacja złożona z dziewięciu rozdziałów, w tym jednego w języku angielskim:

I. Rola odnawialnych źródel energii w rozwiazywaniu globalnego kryzysu energetycznego, Franciszek Krawiec;

II. Perspektywy rozwoju Odnawialnych Żródel Energii (OZE) w Polsce do 2020 roku, Jarosław Juściński;

III. Biopaliwa, Ewa Klugmann-Radziemska, Piotr Meler, Krzysztof Ciunel, Witold Lewandowski;

IV. Wybrane problemy rozwoju sektora biogazu rolniczego w Polsce, Adam Kupczyk, Agnieszka Wójcik, Maria Majkowska;

V. Stan i kierunki rozwoju biomasy dla potrzeb elektroenergetyki polskiej, Jan W. Dubas

VI. Energetyka wiatrowa, Andrzej Chocholski;

VII. Stan i kierunki rozwoju energetyki wiatrowej w USA, Stella Krawiec;

VIII. Rozwój technologii fotowoltaicznych na świecie w dobie ogólnoświatowego kryzysu, Ewa Klugmann-Nadziemska;

IX. Photovoltaics technology beyond the tipping point: the new energy revolution, Lawrence L. Kazmerski.

Autorzy chcą przekonać o tym, że budowa strategii rozwoju Odnawialnych Źródeł Energii i programów DSM (ang. Demand Side Menagement) w celu całkowitego zaspokojenia potrzeb energetycznych społeczności i gospodarek świata jest wyzwaniem dla wszystkich ludzi.

W pierwszym rozdziale Franciszek Krawiec pisze o roli odnawialnych źródeł energii w rozwiązywaniu światowego kryzysu. Jako pierwszy temat przedstawia definicję energii. Wyjaśnia pojęcie nieodnawialnych i odnawialnych źródeł energii, opisuje wpływ, jaki od początku rewolucji przemysłowej i rozwoju współczesnego kapitalizmu wywarło wykorzystywanie brudnych paliw na stan środowiska. Następnie Autor opisuje proces rozwoju przemysłu energetycznego, opisuje jak przedstawiało się zużycie energii w latach sześćdziesiątych XX wieku, pisze o turbinach gazowych, które odegrały znaczącą rolę w technologii wytwarzania energii. Przedstawia przebieg zmian, które w końcowym efekcie doprowadziły do zahamowania wzrostu zapotrzebowania na energię elektryczną w krajach rozwiniętych. W kolejnym podrozdziale Autor przedstawił działania rządu Stanów Zjedno- 
czonych, który postanowił stworzyć prawne uwarunkowania, a także mechanizmy ekonomiczne i stymulacje rynkowe do racjonalnego wykorzystywania energii, podnoszenia efektywności energetycznej urządzeń, rozwoju jak również wdrażania Odnawialnych Źródeł Energii. W roku 2004 nastąpiła era globalnego popytu i podaży energii, ten rok zaznaczony został w historii jako czas, w którym po raz pierwszy wystapił tak duży wzrost zapotrzebowania na energię. Za tak wysoki wzrost zapotrzebowania na energię odpowiadają: ogromny rozwój i wzrost gospodarki chińskiej.

W drugim rozdziale Autor przedstawia perspektywy rozwoju dla Odnawialnych Źródeł Energii w Polsce. Przewiduje się, że ogólnoświatowe zapotrzebowanie na energię w 2030 roku będzie wyższe od obecnego o 50-60\%. Poszukując przyczyn tak znacznego wzrostu wskazuje się na wzrost ludności w państwach rozwijających się, jak również duży wzrost w produkcji energii w krajach Afryki i Azji. W Polsce zasoby energii pierwotnej maja niekorzystną strukturę, dlatego ocenia się, że w przyszłości nabiorą znaczenia takie źródła energii odnawialnej, jak ciepło i energia elektryczna pozyskana podczas utylizacji odpadów przemysłowych i komunalnych, energia słoneczna i geotermalna. W Polsce od kilku lat odnotowuje się wzrost wykorzystywania odnawialnych źródel energii, w szczególności energii wiatru oraz biomasy. Na przestrzeni ostatnich dziesięciu lat dokonano dużego postępu w zakresie poprawy efektywności energetycznej. Zakłada się, że w 2020 roku popyt na energię elektryczną będzie wyższy od obecnego o połowę, a wzrost zapotrzebowania na energie, będzie wymagał dodatkowych inwestycji w nowe moce produkcyjne. Polityka energetyczna Polski zakłada, że do 2020 roku odnawialne źródla energii będą się rozwijać bardzo dynamicznie. Najszybciej rozwijającą się technologią wytwarzającą energie elektryczną z odnawialnych źródeł energii będzie energetyka wiatrowa. Drugim w kolejności rozwijającym się źródłem energii będzie biomasa, następnie biogaz i energetyka wodna. W ostatnim podrozdziale Autor porusza temat energetyki jądrowej. W Polsce, na skutek dużego oporu społecznego oraz nierozwiązanego problemu składowania radioaktywnych odpadów, rozwój energetyki jądrowej w dalszym ciąu wykazuje zastój. Jednak Polska energetyka musi dokonać zmian polegających na zmodernizowaniu i rozbudowie infrastruktury, w celu dostosowania jej do rosnących potrzeb energetycznych, a także wymogów ochrony środowiska.

W trzecim rozdziale Autorzy poruszają temat biopaliw. Rozwój gospodarczy świata wiąże się ze zwiększeniem poziomu i efektywności produkcji, a w konsekwencji, wzrostem poziomu życia. Powoduje to systematyczny wzrost zapotrzebowania na energię elektryczna, cieplną, a także energię mechaniczną wykorzystywaną w środkach transportu, komunikacji oraz rolnictwie. Duży udział we wzroście zużycia energii ma transport spedycyjny, a także ciągły przyrost ilości pojazdów osobowych na świecie. Nie tylko aspekty ekonomiczne były impulsem do poszukiwań innych źródeł energii. W obliczu wzrastającego skażenia środowiska, a zwlaszcza powietrza, za które w sporej części odpowiada spalanie paliw płynnych i gazowych ludzkość zaczęła kłaść większy nacisk na kwestie ekologiczne. Biopaliwa są najczęściej klasyfikowane jako jeden z rodzajów biomasy rozumianej jako paliwo pochodzenia roślinnego, powstającego w procesie fotosyntezy. Pozwala ona w naturalny sposób ograniczyć emisję dwutlenku węgla, który przez naukowców uważany jest za głównego sprawcę globalnego ocieplenia. Bardzo ważnym czynnikiem, mającym wpływ na potencjal możliwości wykorzystania biopaliw do zwalczania skutków kryzysu energetycznego są odpowiednie przepisy prawne, które określą warunki produkcji i obrót biopaliwami. W Polsce, zalożenia do rozwoju energetyki odnawialnej obejmujace regulacje 
związane z produkcją i zagospodarowaniem biopaliw są określone w Strategii rozwoju energetyki odnawialnej. Jest to dokument rządowy przyjęty przez Sejm w sierpniu 2001 roku.

Kolejny rozdział, w którym prezentują opracowania Adam Kupczyk, Agnieszka Wójcik oraz Maria Majkowska, prezentuje problemy rozwoju sektora biogazu rolniczego. Biogazownie są obiektami o prostej konstrukcji, tanimi i efektywnymi. Surowcem wykorzystywanym do produkcji biogazu są nawozy zwierzęce oraz resztki organiczne z gospodarstw domowych, które dalej przerabiane są w trybie fermentacji periodycznej (regularnej) jest to fermentacja metanowa, gdzie raz do roku komory fermentacyjne zostają opróżniane i substrat wywozi się na pola jako nawóz. Zmagazynowany biogaz jest wykorzystywany głównie na potrzeby własnego gospodarstwa. W Europie biogazownie rolnicze są szeroko rozpowszechnione i caly czas rozwijają się. Jako biogazowego lidera podaje się Niemcy - 5000 biogazowni, następnym krajem o wysokim poziomie takich instalacji jest Wielka Brytania. Lącznie te kraje wytwarzają niemal 70\% produkcji biogazu w Unii Europejskiej. Słaby rozwój sektora biogazu thumaczy się dużymi barierami społecznymi, organizacyjnymi, techniczno-technologicznymi bądź ekonomiczno-prawnymi.

W piątym rozdziale Jan W. Dubas przedstawia stan oraz kierunki rozwoju biomasy dla potrzeb polskiej bioenergetyki. We wstępie rozdziału Autor podaje definicję biomasy. Według niego za biomasę uważa się masę materii zawartą w organizmach. Według definicji Unii Europejskiej biomasa obejmuje podatne na rozkład biologiczny odpady i pozostałości przemysłu rolnego, leśnictwa i związanych z nimi gałęzi gospodarki, jak również odpady przemysłowe i miejskie, które ulegają biodegradacji. Definicja ta oddaje istotę rzeczy w odniesieniu do jej wykorzystania w procesie przetwórczym energii pierwotnej do innych szlachetniejszych form, jakimi są ciepło i energia elektryczna. Pierwotnie biomasę wykorzystywano głównie do ogrzewania i oświetlenia, obecnie jej wykorzystanie wiąże się $\mathrm{z}$ ograniczeniem emisji $\mathrm{CO}_{2}$ do atmosfery. Biomasa składa się $\mathrm{z}$ trzech podstawowych składników: celulozy, hemicelulozy i ligniny. Razem te składniki tworzą potencjał energetyczny biomasy. W Polsce biomasa pozyskiwana jest z użytków leśnych i rolnych. Z użytków leśnych można by pozyskać ją z drewna małowymiarowego, jednak dla jednostek dużej energetyki są to zbyt małe pokłady więc pozostaje wykorzystanie biomasy pozyskiwanej z użytków rolnych takich jak: słoma, ziarno zbóż, siano bądź rzepak. Z wielu analiz wynika, że największy potencjał energetyczny posiada słoma, ale jako paliwo posiada wady, jedną z nich jest: dla dużej objętości zbyt mała wartość energetyczna. Według przedstawionych prognoz rozwoju wykorzystania odnawialnych źródeł energii do 2030 roku najszybciej rozwijać się będzie biomasa pochodząca z upraw roślin energetycznych. Jednak duża energetyka nie jest zainteresowana budową rynku biomasy w Polsce. Podstawowa przyczyną takiego zjawiska jest import taniej biomasy z rynku poza Unią Europejska.

Andrzej Chochowski poświęcił rozdział energetyce wiatrowej. W rozdziale szóstym przedstawia zasoby, jakie posiada Polska, biorąc pod uwagę energię wiatrową. Polska leży w strefie o średnich warunkach wietrzności, gdzie prędkość wiatru utrzymuje się na poziomie od 3,5 do 4,5 m/s. Aby móc wykorzystywać energię wiatru, jego prędkość musi wynosić powyżej $4 \mathrm{~m} / \mathrm{s}$. Takie warunki spełnia $2 / 3$ terytorium Polski. Jednak najlepsze warunki panują na wybrzeżu i Suwalszczyźnie. Technologia pozyskiwania energii z wiatru znana jest od dawna, na przestrzeni ostatnich 30 lat nastąpił dynamiczny rozwój konstrukcji oraz jej doskonalenie. Autor zamieścił w rozdziale wiele wykresów, map aby w przejrzysty sposób przedstawić np. średnie prędkości wiatru, rozkład zasobów energii wiatru w Polsce, wykres jako przykładowy histogram średniej prędkości wiatru. Są to szczegółowe dane 
potrzebne do analizy, która wykaże jakie turbiny można instalować, w jakich regionach aby uzyskać pożądane moce energii wiatrowej. Każdego roku na skutek postępu technologicznego wzrasta moc oraz wielkość silowni wiatrowych. Zainteresowanie wykorzystywaniem energii wiatru wciąż rośnie, sprzyja temu nie tylko obowiązujące prawo, wymagania unijne ale również nowoczesne rozwiązania i pozytywne opinie sąsiednich krajów.

W kolejnym rozdziale Autorka opracowania - Stella Krawiec przedstawiła stan oraz kierunki rozwoju energii wiatrowej w Stanach Zjednoczonych. Głównym celem jej pracy jest ocena rozwoju oraz wyzwań produkcji energii wiatrowej w USA i innych przodujących krajach. Według Autorki do 2030 roku zapotrzebowanie na energię elektryczną przez cały czas będzie rosło. Wzrost zapotrzebowania wiąże się z planowaniem nowych inwestycji w moce wytwórcze. W perspektywie do 2020 roku jednostki wytwórcze zasilane spalaniem gazu ziemnego będą sukcesywnie zastępowane przez inne moce wytwórcze energii elektrycznej. Według prognoz amerykańskich naukowców w latach 2000-2020 będzie potrzeba $355 \mathrm{GW}$ nowych mocy wytwórczych żeby zastąpić jednostki, które zostaną wycofane z eksploatacji. Przewidywane są glównie turbiny wiatrowe, jednostki geotermiczne oraz jednostki, które zasilane są energiąze spalania odpadów stalych. Zakłada się, że w 2020 roku produkcja energii elektrycznej produkowana przez odnawialne źródła energii wzrośnie z 81 miliardów $\mathrm{kWh}$ do 160 miliardów $\mathrm{kWh}$. W 2006 roku USA odzyskało wiodącą pozycję w przemyśle wiatrowym po dziesięcioletnim pozostawaniu w tyle za Niemcami i Hiszpania. Od 2006 roku Stany Zjednoczone są liderem w rozwoju przemysłu wiatrowego. Dzięki rozwojowi tej dziedziny uda się zmniejszyć emisję $\mathrm{CO}_{2}$ do atmosfery o 44 miliony ton (dla porównania jest to zanieczyszczenie pochodzące od 7 milionów pojazdów). Na końcu rozdziału zostały przedstawione: analiza kosztów oraz ceny energii wiatrowej. Strukturę kosztów zakupu i instalacji turbiny wiatrowej oraz średnią realną cenę energii elektrycznej wytworzonej przez systemy wiatrowe Autorka zamieścila w dwóch tabelach, w strukturze kosztów typowej turbiny mieści się: turbina (75\% udziału w kosztach), przyłączenie do sieci, fundament, dzierżawa ziemi, instalacje elektryczne, budowa drogi dojazdowej, usługi konsultacyjne oraz systemy kontrolne. Natomiast na średnioważoną cenę składają się czynniki tj.: zasoby wiatru, istniejąca infrastruktura, koszty przesyłu, adekwatność zasobów czy transport.

W ostatnim rozdziale polskojęzycznym Autor porusza temat fotowoltaiki. W obecnym czasie jest to energia, która spełnia wszystkie kryteria jakie stawia się źródłom energii przyjaznym środowisku. Jest to energia Słońca, powszechnie dostępna, natomiast ogniwa i moduly fotowoltaiczne są jednymi z najbezpieczniejszych urządzeń do przetwarzania energii z punktu widzenia ochrony środowiska. W państwach wysoko rozwiniętych nakłady na inwestycje w zakresie fotowoltaiki są z roku na rok coraz większe. Technologia fotowoltaiczna daje wysokie korzyści ekonomiczne, jak i społeczne użytkownikom tj. znacząca redukcja emisji $\mathrm{CO}_{2}$ i nowe miejsca pracy. Przemysł w tej dziedzinie jest jednym z najintensywniej rozwijających się na świecie, w 2007 roku w ten sektor zainwestowano około 30 mld dolarów amerykańskich. Czołowymi inwestorami w linie produkujące ogniwa i moduły PV są: Niemcy, ChRL, USA, Hiszpania, Japonia i Indie. W Polsce obserwowany jest brak znaczącego postępu w ilościach instalowanych systemów PV. Istotny wplyw na rozwój instalacji fotowoltaicznych maja: regulacje budowlane, zbiór przepisów dla zielonych budynków, cena za kWh energii elektrycznej pochodzącej z OZE, jak również prowadzona odpowiednia polityka krajowa, regionalna i lokalna dla odnawialnych źródeł energii. W Polsce okres zwrotu inwestycji dla systemu PV jest długi, wynosi ok. 20 lat, dlatego nie 
znajduje powszechnego zastosowania. Jednak istnieje perspektywa obniżenia okresu zwrotu energii elektrycznej z kilkudziesięciu nawet do kilku lat, jeżeli zostaną spełnione określone uwarunkowania dotyczące zarówno technologii produkcji, jak i eksploatacji modułów. Wiąże się to $\mathrm{z}$ zastosowaniem ogniw $\mathrm{z}$ krystalicznego krzemu.

Rozdział dziewiaty zostal opracowany w języku angielskim przez Lawrenca L. Kazmerskiego. Autor podejmuje temat technologii ogniw fotowoltaicznych jako punkt zwrotny rewolucji energetycznej.

W analizowanej publikacji w sposób przejrzysty i zrozumiały przedstawiono zlożone problemy, z jakimi boryka się świat w dobie globalnego kryzysu energetycznego. Wzrost populacji świata czy pogłębiający się efekt cieplarniany wywołały kryzys energetyczny, który wymaga wysiłku całej ludzkości w dążeniu do obniżenia zużycia energii z dotychczasowych źródel i szukania takich, które będą w stanie zaspokoić popyt w jak najmniejszym stopniu szkodząc środowisku naturalnemu. W publikacji zawarto wiele ciekawych informacji, które można wykorzystać w zarządzaniu energetyką. Autorzy wiele informacji przedstawiaja w tabelach, wykresach, mapach co daje bardzo przejrzysty obraz omawianych kwestii. W publikacji przedstawiono obecny stan wykorzystywania odnawialnych źródeł energii w Polsce i na świecie, zawarto również prognozy jak będzie rozwijało się zapotrzebowanie na energię z OZE w przyszłości, wskazano na działania, które mogły by pomóc w rozwoju energii z produktów, które są zwykłymi odpadami w gospodarstwie domowym i bariery, które utrudniaja wykorzystanie naturalnych produktów do produkcji bioenergii. Sa to bardzo ciekawe informacje dla wszystkich ludzi znających stan zasobów środowiska naturalnego, jak je wykorzystywać, aby następne pokolenia ludzkości mogły korzystać $z$ dóbr przyrody jak najdłużej.

Autorzy poszczególnych rozdziałów wnikliwie i wyczerpująco charakteryzują wybrane tematy zachęcając czytelnika do szerszego zapoznania się z opisywanymi zagadnieniami. Niewątpliwą zaletą monografii jest jej język, zrozumiały i przejrzysty.

Wojciech STANKIEWICZ

Uniwersytet Warmińsko-Mazurski, Olsztyn

\section{Peter Warren Singer, Wired for War The Robotics Revolution and Conflict in the Twenty-first Century, Penguin Press, Nowy Jork 2009, ss. 512.}

Peter Warren Singer jest amerykańskim badaczem studiów strategicznych młodego pokolenia. Jego dotychczasowy dorobek obejmuje zaledwie trzy publikacje książkowe (włączenie $\mathrm{z}$ recenzowana), jednak wszystkie one podejmują nowe, obiecujące tematy, które z czasem weszly do kanonu naukowej debaty na temat konfliktów zbrojnych. Peter Singer specjalizuje się w badaniach zmian zachodzących w charakterze konfliktów zbrojnych na przełomie XX i XXI wieku. Dwie pierwsze monografie jego autorstwa (Corporate Warriors: The Rise of the Privatized Military Industry oraz Children at War), były pionierskimi pracami, poruszającymi temat nowych kategorii uczestników konfliktów zbrojnych, tzn. odpowiednio prywatnych firm wojskowych oraz dzieci-żołnierzy. Oba zagadnienia stały się z czasem przedmiotem żywego zainteresowania oraz debaty, tak naukowej, jak i publicystycznej. 